\title{
Failure analysis of No.2 main transformer in Fushun SiShui substation
}

\author{
Tianshu Hai ${ }^{1}$, Xin $\mathrm{Liu}^{1}$, Chengcheng Yue ${ }^{1}$, Bo $\mathrm{Li}^{1}$, Yan $\mathrm{Liu}^{2}$, Jingzhong $\mathrm{Li}^{1}$, Jie \\ $\mathrm{Sun}^{1}$, Yang $\mathrm{Hu}^{1}$, Ying $\mathrm{Li}^{1}$, Wenfeng $\mathrm{HaO}^{1}$ \\ ${ }^{1}$ Fushun Power Supply Company, Liaoning Electric Power Company Limited, State Grid, China \\ 2 Jinzhou Power Supply Company, Liaoning Electric Power Company Limited, State Grid, China
}

Keywords: transformer; outlet short circuit; turn-to-turn short circuit; short circuit current; three ratio method

\begin{abstract}
. the transformer is one of the most important equipment in power system, the maximum short current rated current is 25 30 times or more when an outlet short circuit occurs,short current will produce great mechanical force which is hundreds of times larger than the normal operation, Under the action of the huge short circuit electromagnetic force, many components such as the winding of the transformer may be damaged. This paper describes the whole process of of 2\# main transformer in Fushun SiShui substation accident analysis, and the turn-to-turn short circuit accident of the winding is caused by interphase short circuit of the cable, this also provides a scientific basis for the transformer's fault detection.
\end{abstract}

\section{Introduction}

The transformer is one of the most important equipment in power system, Whether it is power plants, substations, transmission and distribution network, or the vast number of users and the various sectors of the national economy, are using a variety of transformers, because of the high cost and the status of the transformer, once the transformer accident will bring huge losses to the national economy. Transformer faults are generally divided into two categories In nature: thermal fault and discharge fault. Thermal failure is usually shown as the local overheating of the transformer and the temperature increases. According to its severity, thermal failure is often divided into four types: Mild overheating (generally less than $150{ }^{\circ} \mathrm{C}$ ). Low temperature overheating (from 150 to $300^{\circ} \mathrm{C}$ ), medium temperature overheating (from 300 to $700{ }^{\circ} \mathrm{C}$ ) and high temperature overheating (above $700^{\circ} \mathrm{C}$ ). The discharge fault is usually the degradation or deterioration of the transformer's insulation performance under the high electric field strength. According to the different energy density of the discharge, it can be divided into three types: partial discharge, spark discharge and high energy arc discharge; According to the discharge of different parts, it is divided into Air gap discharge of the folding screen, Spark discharges between different potential insulation, Spark discharge caused by suspended potential, arborization discharge of the folding screen, Arc discharge caused by the dislocation tap switch, multipoint earthing discharge of the iron core, Power frequency continuation discharge, the turn-to-turn short circuit discharge of the winding, winding to ground discharge and so on.

\section{The harm of transformer exit short circuit}

Current carrying cond in a magnetic field must bear the function of mechanical force, Therefore, due to the role of the current and the leakage magnetic field, the winding will produce electromagnetic force when the current flows the transformer winding, its magnitude is determined by the product of the leakage magnetic flux density and the wire current, The calculation formula of the wire force per unit length is $\mathrm{f}=\mathrm{Bli}$, The direction of the force is determined by the left hand rule. When the transformer operates under normal load, the force acting on the wire is very small, However, due to the outlet short circuit, the maximum short current will be 25 30 times or even greater than the rated current, and the electromagnetic force generated in the short circuit is proportional to the square of the short current(because the electromagnetic force per unit length $\mathrm{f}=\mathrm{B}$ 
$\times I$, and Magnetic flux density B is proportional to the current I, so the $F\left(f^{\circ}\right.$ ), So the mechanical force is hundreds of times larger than the normal operation when short current, and the force produced very quickly, circuit breaker is too late to cut off the circuit in such a short time. Thus, Therefore, under the action of the huge short circuit electromagnetic force, many components such as the winding of the transformer can be damaged.

\section{The accident case}

SiShui substation is the Ministry of infrastructure projects, it put into operation in 2014 October after the acceptance, it is the use of YouGao 2\# line with a main transformer running before fault, and it is running with all the load, $10 \mathrm{kV}$ bus-bar switch is closed. The YouGao 1\# line has not been formed, so $1 \#$ main transformer isn't in an operation state. Its load is $2.2 \mathrm{MW}$ before fault. August 1 , 2016 at 14:49, heavy gas action occurred in Fushun SiShui substation, the primary and the secondary side switch the secondary side were trip and the substation was blackout, the action process is shown in Table 1.

Table 1 The schedule of the tansformer tripping operation

\begin{tabular}{|c|l|c|c|}
\hline Order Number & Time & Device Name & Phenomenon \\
\hline 1 & August 1, 2016 14:49:53 & $\begin{array}{c}\text { The 10kV side 10622 intervals of 2\# } \\
\text { main transformer in SiShui substation }\end{array}$ & $\begin{array}{c}\text { Signal } \\
\text { action }\end{array}$ \\
\hline 2 & August 1, 2016 14:49:53 & $\begin{array}{c}\text { Heavy gas outlet of 2\# main } \\
\text { transformer in SiShui substation }\end{array}$ & Action \\
\hline 3 & August 1, 2016 14:49:54 & $\begin{array}{c}\text { The secondary side 10622 switch of 2\# } \\
\text { main transformer in SiShui substation }\end{array}$ & $\begin{array}{c}\text { Opening } \\
\text { position }\end{array}$ \\
\hline 4 & August 1, 2016 14:49:54 & $\begin{array}{c}\text { The secondary side 10622 switch of 2\# } \\
\text { main transformer in SiShui substation }\end{array}$ & $\begin{array}{c}\text { Opening by } \\
\text { Accident }\end{array}$ \\
\hline 5 & August 1, 2016 14:49:54 & $\begin{array}{c}\text { Heavy gas outlet of 2\# main } \\
\text { transformer in SiShui substation }\end{array}$ & Returning \\
\hline 6 & August 1, 2016 14:49:54 & $\begin{array}{c}\text { 10622 switch of YouGao 2\# line in } \\
\text { SiShui substation }\end{array}$ & $\begin{array}{c}\text { Opening } \\
\text { position }\end{array}$ \\
\hline 7 & August 1, 2016 14:49:55 & $\begin{array}{c}\text { Light gas alarm of 2\# main transformer } \\
\text { in SiShui substation }\end{array}$ & Action \\
\hline 9 & August 1, 2016 14:49:55 & $\begin{array}{c}\text { Heavy gas outlet of 2\# main } \\
\text { transformer in SiShui substation }\end{array}$ & Action \\
\hline
\end{tabular}

Operation personnel rushed to the scene,and then found that there was a large amount of gas in the buchholz relay of 2\# main transformer, they carried out the ignition test and found that the gas was combustible.So the maintenance and test personnel are informed to carry on the test on the 2\# main transformer and the gas, The test data is shown in Table 2.

Table 2 The oil chromatography data of 2\# main transformer

\begin{tabular}{|c|c|c|c|c|c|c|c|c|}
\hline \multirow{2}{*}{ Component } & \multicolumn{8}{|c|}{ content $(\mu \mathrm{l} / \mathrm{L})$} \\
\cline { 2 - 9 } & $\mathrm{H}_{2}$ & $\mathrm{CO}$ & $\mathrm{CO}_{2}$ & $\mathrm{CH}_{4}$ & $\mathrm{C}_{2} \mathrm{H}_{6}$ & $\mathrm{C}_{2} \mathrm{H}_{4}$ & $\mathrm{C}_{2} \mathrm{H}_{2}$ & $\mathrm{C}_{1}+\mathrm{C}_{2}$ \\
\hline Gas & 209028 & 156624 & 2415 & 20766.42 & 799.45 & 17753.55 & 30909.05 & 70228.47 \\
\hline Theoretical value of gas oil & 12542 & 18795 & 2222 & 8098.9 & 1838.74 & 25920.18 & 31527.23 & 67385.05 \\
\hline Upper part & 350 & 382 & 712 & 122.04 & 17.92 & 243.22 & 426.69 & 809.87 \\
\hline Lower part & 334 & 374 & 697 & 99.9 & 10.78 & 149.65 & 273.11 & 533.44 \\
\hline
\end{tabular}

Judging from the analysis of oil chromatography: a case study on the oil chromatography of the transformer's lower part. The value of $\mathrm{C} 2 \mathrm{H} 2$ is $273,11 \mu \mathrm{l} / \mathrm{L}>5 \mu \mathrm{l} / \mathrm{L}$ (standard), it shows that there is a serious discharge fault in the transformer, three ratio method: $\mathrm{C} 2 \mathrm{H} 2 / \mathrm{C} 2 \mathrm{H} 4=273.11 / 149.65=1.82$, because $1<1.82<3$, so the ratio of three ratio method is encoded as " 1 "; $\mathrm{CH} 4 / \mathrm{H} 2$ $=99.9 / 334=0.3$, because $0.1<0.3<1$,so the ratio of three ratio method is encoded as " 0 "; fault property belongs to high energy discharge fault, the fault location should be between the coil、 
between the conductor turn or between the coil to the ground. The test data show that there is a high energy discharge fault in the transformer, leading to the primary and the secondary side switch trip, light and heavy gas action occurred in the transformer.

\section{The analysis of accident cause}

According to the change of the main transformer and coil, the cause of the accident is:

(1) there are defects in the construction technology of end insulation

according to the requirements, the cotton tape was used to tie end insulation to the first conductor turn,the method is " 8 "bandaging, and the thick plate groove $(0.5 \mathrm{~mm})$ was put in the head(The head of the transformer is not covered with cardboard), end insulation thickness should be less than the wire thickness. Loosening phenomenon is happened on the first end of the A phase coil(Unlocked), The electric force causes the vibration friction, leading to insulation damage during the operation

(2) Exit short circuit of the secondary side occurred many times

The econdary side of the transformer has a There is a $5.4 \mathrm{~km}$ long power cable for $10 \mathrm{kV}$ Gaokan line, There are 7 joints in the middle of the cable, of which the 5 joints have cable wells, and the other 2 are directly buried underground. From August 2014 to October, the grapple truck was adopted for laying cables, the traction force of the grapple truck was too large, the failure happened after the completion of the cable laying, then repaired the power transmission. Due to the large number of the cable joint, the insulation hazard during construction, and the cable connector is used "thermal head"( Thermal head is not usually used in the middle of the joints without special treatment,because the problem of Elastic easily disappear the ,bad tightness , heat shrinkable material easy corrosion and aging problems), As shown in Figure 6, there is a problem of quality. The continuous heavy rain in July 2016 led to the 2 phase short circuit or grounded trip, After a few days of moisture exclusion,, and insulation was recovered, forced to supply electricity successfully.

August 1, 2016 14:49:53 , The cable fault causes the 10kV side 10622 intervals of 2\# main transformer in SiShui substation to send out the accident signal and act, the cable cable causes the 2\# main transformer to produce the turn (layer) the short circuit discharge. August 1, 2016 14:49:55, light and heavy gas action occurred in 2\# main transformer in SiShui substation. After the accident of 2\# main transformer,1\# main transformer was supplied electricity In August 5, 2016, cable defect immediately exposed after 3 hours tunning, the switch of $10 \mathrm{kV}$ Gaokan line triped again. the 3 joints of the cable had been breakdown and burning loss when finding cable fault in August 6 to 8 . As shown in Figure 1 and 2,two holes have been burned in A and B phase, This also shows that the cable fault is very serious, such a serious fault is not only caused by an accident, but most of the cumulative results of several accidents.

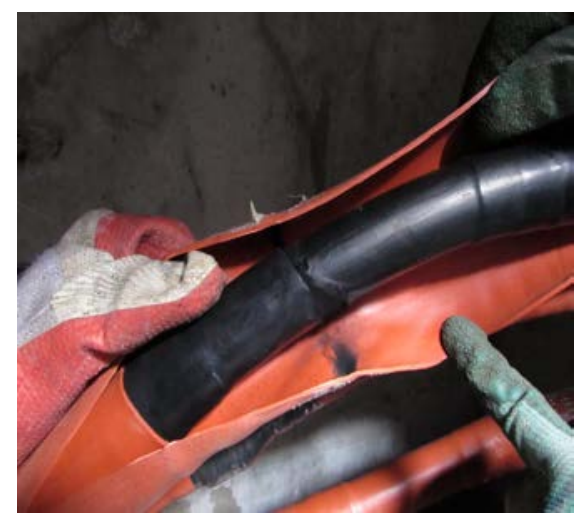

Fig.1

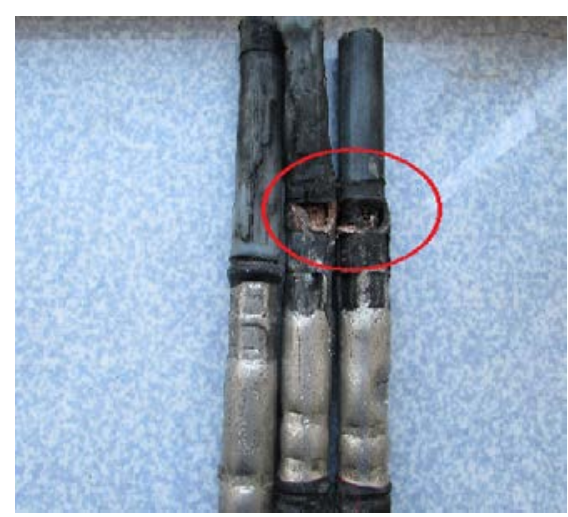

Fig. 2

Conclusion: The construction personnel stay hidden in the cable construction, Thermal head became dampness during the operation,and then insulation discharge accident occurred, which occurred outlet short circui in the secondary side of the transformer. Under the action of the larger 
short circuit current,the electric power and the problem in transformer manufacture technology, the transformer happened winding deformation and the turn (layer) short circuit discharge accident.

\section{Hanging core checked and certified}

The model of 2\# main transformer in SiShui substation is SZ11-40000/66, The manufacturer is Shandong taikai Transformer Co. Ltd., it left the factory on June 2014, and in the year of October put into operation. After the communication with the factory, 2\# main transformer of SiShui substation was separated from GIS and then returned to factory for inspection and maintenance on August 172016 to19. Fushun company assigned a special person to cooperate with the provincial company experts to inspect the cause of the problem

In August 24th, the staff checked the transformer by hanging core,and they found that A phase of the high-tension coil had burning traces in the head position, A phase of platen had Insulation damage in the head position,and no obvious abnormality was found in other location. the morning of August 25th ,The staff broke down and checked the main transformer coil in coil department to find out the specific reasons.Through the inspection found that the conductor wire between the second and the third section of the high-pressure coil A phase is burning loss seriously,the insulation of wire is carbonization. As shown in Figure 3 and Figure, which shows that the conclusion of high energy discharge fault in transformer internal by the chromatographic analysis is correct.

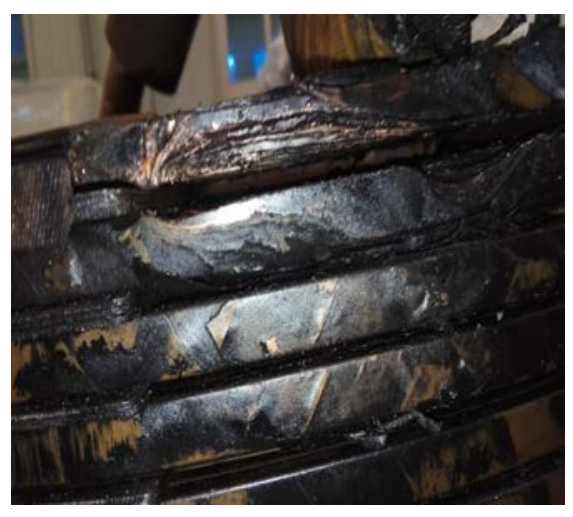

Fig. 3

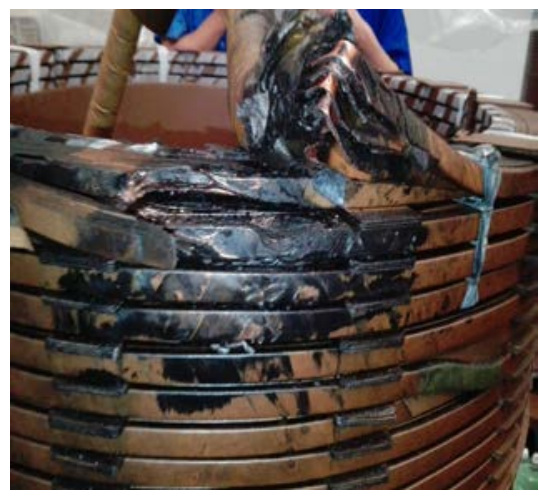

Fig.4

\section{Conclusion}

To avoid the short circuit of transformer is the key to ensure the safe operation of transformer from 2\# main transformer accident in SiShui substationg.Therefore, not only to prevent external conditions which may lead to short circuit, but also must study the transformer on the short circuit force tolerance and check on the mechanical strength of the winding in exit short circuit conditions in the transformer design.

\section{References}

[1] Dong Qiguo. Fault diagnosis of power transformer[M]. Beijing: China power press, 2000

[2] Chen Wei. Electrical equipment preventive testing technical questions and answers [M]. Beijing: hydraulic and electric power press, 1998

[3] Chen Huagang. Electrical equipment preventive testing method [M]. Beijing: Water conservancy and electric power press, 1999

[4] Cao Dunkui. Transformer oil chromatographic analysis and fault diagnosis[M]. Beijing: Chinese power press, 2011

[5] Wang Shige, Zhong Hongbi. Power transformer fault analysis and technical improvement[M]. Beijing: China power press, 2004 